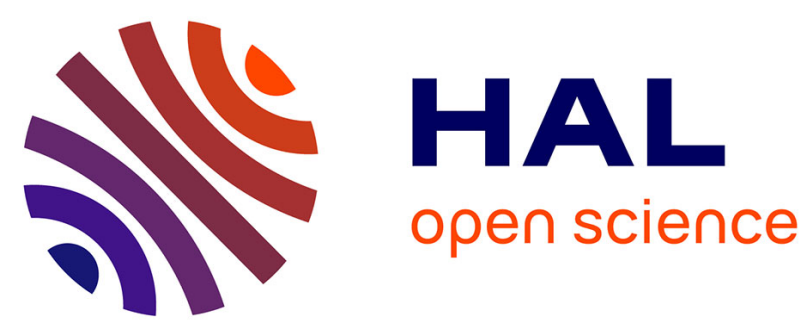

\title{
Synthesis, characterization, and electrochemical behavior of mixed-ligand complexes of cobalt(III) with dimethylglyoxime and some amino acids.
}

A. Adkhis, S. Djebbar, O. Benali-Baïtich, A. Kadri, Mustayeen A. Khan, G. Bouet

\section{To cite this version:}

A. Adkhis, S. Djebbar, O. Benali-Baïtich, A. Kadri, Mustayeen A. Khan, et al.. Synthesis, characterization, and electrochemical behavior of mixed-ligand complexes of cobalt(III) with dimethylglyoxime and some amino acids.. Synthesis and Reactivity in Inorganic and Metal-Organic Chemistry, 2003, 33 (1), pp.35-50. 10.1081/SIM-120016871 . hal-03224710

\section{HAL Id: hal-03224710 \\ https://univ-angers.hal.science/hal-03224710}

Submitted on 13 May 2021

HAL is a multi-disciplinary open access archive for the deposit and dissemination of scientific research documents, whether they are published or not. The documents may come from teaching and research institutions in France or abroad, or from public or private research centers.
L'archive ouverte pluridisciplinaire HAL, est destinée au dépôt et à la diffusion de documents scientifiques de niveau recherche, publiés ou non, émanant des établissements d'enseignement et de recherche français ou étrangers, des laboratoires publics ou privés. 


\title{
Synthesis, Characterization, and Electrochemical Behavior of Mixed-Ligand Complexes of Cobalt(III) with Dimethylglyoxime and Some Amino Acids
}

\author{
A. Adkhis, ${ }^{1}$ S. Djebbar, ${ }^{1}$ O. Benali-Baïtich, ${ }^{1, *}$ A. Kadri, ${ }^{2}$ \\ M. A. Khan, ${ }^{3}$ and G. Bouet ${ }^{3}$ \\ ${ }^{1}$ Laboratoire d'Hydrométallurgie et de Chimie Inorganique \\ Moléculaire, Faculté de Chimie, USTHB, El Alia, \\ Bab Ezzouar, Alger, Algeria \\ ${ }^{2}$ Laboratoire de Matériaux Electrochimie et Corrosion, \\ Université M. Mammeri, Tizi-Ouzou, Algeria \\ ${ }^{3}$ Laboratoire de Chimie de Coordination, Faculté de Pharmacie, \\ Université d'Angers, Angers, France
}

\begin{abstract}
The syntheses of non-electrolyte complexes of the general formula $\left[\mathrm{Co}(\mathrm{Hdmg})_{2}(\mathrm{HA}) \mathrm{X}\right]$, where $\mathrm{Hdmg}=$ dimethylglyoximato monoanion, $\mathrm{HA}=$ glycine (Gly), Serine (Ser), Cysteine (Cys) or Cystine (Cys-Cys)
\end{abstract}

\footnotetext{
*Correspondence: O. Benali-Baïtich, Laboratoire d' Hydrométallurgie et de Chimie Inorganique Moléculaire, Faculté de Chimie, USTHB, BP32, El Alia, Bab Ezzouar, Alger, Algeria; E-mail: benali-baitich@netcourrier.com.
}

35

DOI: $10.1081 /$ SIM-120016871

Copyright (C) 2003 by Marcel Dekker, Inc.

0094-5714 (Print); 1532-2440 (Online) www.dekker.com 
and $\mathrm{X}=\mathrm{Cl}, \mathrm{Br}, \mathrm{I}, \mathrm{SCN}$ are described. The structure of the complexes proposed according to elemental analyses, IR, UV-Visible and ${ }^{1} \mathrm{H}$ NMR spectra is pseudo-octahedral. The cyclic voltammograms in DMSO at a GC disk electrode consist of two processes (I and II) corresponding to oxidations, whereas the redox systems III and IV appear to be associated with reduction processes. The $\mathrm{Co}(\mathrm{II}) / \mathrm{Co}(\mathrm{I})$ redox couple is reversible for various complexes and is relatively insensitive to the axial ligand. The $\mathrm{Co}(\mathrm{III}) / \mathrm{Co}(\mathrm{II})$ couple depends on the axial ligation, shows chemical irreversibility and has a much slower rate of electron transfer than the $\mathrm{Co}$ (II)/Co(I) couple due to the strong binding of the Lewis base to the $\mathrm{Co}(\mathrm{III})$ ion.

\section{INTRODUCTION}

The chemistry and the molecular structure of complexes of the type $\left[\mathrm{Co}(\mathrm{Hdmg})_{2} \mathrm{RX}\right]$, called cobaloximes, (where $\mathrm{X}=$ Lewis bases, Hdmg $=$ dimethylglyoxime monoanion, $\mathrm{R}=$ alkyl group) have been previously described. ${ }^{[1-3]}$ These compounds are interesting on one hand, because of their extensive coordination chemistry, ${ }^{[4,5]}$ and on the other hand, because of their relevance to the chemistry of vitamin $B_{12} \cdot{ }^{[6,7]}$ As models for coenzyme $B_{12}$, cobaloximes have been subjected to extensive studies including their electrochemical $^{[8]}$ and structural properties. ${ }^{[9]}$

As part of our interest in the preparation of cobaloximes, we have previously reported the synthesis and studies ${ }^{[10]}$ of $\left[\mathrm{Co}(\mathrm{Hdmg})_{2}(\mathrm{HA}) \mathrm{X}\right]$ (where $\mathrm{HA}=$ alanine, threonine and histidine). As a continuation of our work on similar complexes, we have now extended this chemistry to the synthesis of a new series of cobalt(III) bis(dimethylglyoximato) complexes containing Gly, Ser, Cys and Cys-Cys as amino acid ligand and other halide or pseudo-halide ligands $(\mathrm{X}=\mathrm{Cl}, \mathrm{Br}, \mathrm{I}, \mathrm{SCN})$. The synthesis, characterization and spectroscopic data for all these complexes are detailed below.

\section{EXPERIMENTAL}

\section{Materials}

All chemical reagents and solvents used in the synthesis of the complexes were Fluka p.a. grade products and were used without further purification. The amino acids used were: glycine (Gly), $\mathrm{L}(+)$ serine (Ser), $\mathrm{L}(+)$ cysteine (Cys) and L(-)cystine (Cys-Cys). 


\section{Preparation of Complexes}

\section{Complexes $\left[\mathrm{Co}(\mathrm{Hdmg})_{2}(\mathrm{Gly}) \mathrm{X}\right] \cdot 3 \mathrm{H}_{2} \mathrm{O}(\mathrm{X}=\mathrm{Cl}, \mathrm{Br}, \mathrm{I}, \mathrm{SCN})$}

To a solution of $\mathrm{CoCl}_{2} \cdot 6 \mathrm{H}_{2} \mathrm{O}(2.38 \mathrm{~g}, 10 \mathrm{mmol})$ for the preparation of the chloro complexes or to a solution of $\mathrm{Co}\left(\mathrm{NO}_{3}\right)_{2} \cdot 6 \mathrm{H}_{2} \mathrm{O}(2.91 \mathrm{~g}, 10 \mathrm{mmol})$ in EtOH $(30-40 \mathrm{~mL})$ for the synthesis of all other complexes was added solid $\mathrm{H}_{2} \mathrm{dmg}(2.32 \mathrm{~g}, 20 \mathrm{mmol})$ and amino acid (Gly) $(0.75 \mathrm{~g}, 10 \mathrm{mmol})$. The mixture was stirred for $10 \mathrm{~min}$. Solid $\mathrm{NaBr}(1.02 \mathrm{~g}, 10 \mathrm{mmol}), \mathrm{NaI}$ $(1.50 \mathrm{~g}, 10 \mathrm{mmol})$ or $\mathrm{KSCN}(0.97 \mathrm{~g}, 10 \mathrm{mmol})$ was then added and airoxidation was achieved by stirring vigorously in air for $45 \mathrm{~min}$ to $1 \mathrm{~h} 30$ min. The complexes precipitated and were isolated by filtration, washed with $\mathrm{EtOH}$, diethyl ether and dried in air.

\section{Complexes $\left[\mathrm{Co}(\mathrm{Hdmg})_{2}(\mathrm{Ser}) \mathrm{X}\right] \cdot \mathrm{nH}_{2} \mathrm{O}(\mathrm{X}=\mathrm{Cl}, \mathrm{Br}, \mathrm{I}, \mathrm{SCN})$}

These complexes were prepared as described above in 50 to $70 \mathrm{~mL}$ of EtOH and stirring for $2-3 \mathrm{~h}$.

\section{Complexes $\left[\mathrm{Co}(\mathrm{Hdmg})_{2}(\mathrm{HA}) \mathrm{SCN}\right](\mathrm{HA}=\mathrm{Cys}, \mathrm{Cys}-\mathrm{Cys})$}

These complexes were prepared as described above in 50 to $70 \mathrm{~mL}$ of aqueous EtOH (50\% vol./vol.). The mixture was stirred for 3-4 h.

\section{Physical Measurements}

The elemental analyses were carried out at the Service Central d'Analyse du CNRS (Vernaison, France). Conductance values were obtained with a Tacussel CD-810 conductimeter at room temperature in $10^{-3}$ mol. $\mathrm{L}^{-1}$ solutions of the complexes in DMSO. The IR spectra of solid samples (KBr discs) in the range $400-4000 \mathrm{~cm}^{-1}$ were recorded on a Shimadzu FTIR-9101 M spectrophotometer. The electronic absorption spectra of solutions of the complexes in DMSO were recorded on a Shimadzu UV-1601 UV-Visible spectrophotometer in the range $250-950 \mathrm{~nm}$. The ${ }^{1} \mathrm{H}$ NMR spectra were obtained with a Jed GSX 270 MSB $(270 \mathrm{MHz})$ spectrophotometer in DMSO- $d_{6}$ solution for the complexes and for the dimethylglyoxime ligand, and in $\mathrm{D}_{2} \mathrm{O}$ solution for the amino acid ligands, using TMS as internal reference (Service Commun de RMN, Université d'Angers). The electrochemical experiments were carried out using a 273EGG potentiostat-galvanostat. A typical three-electrode cell was used. The 
working electrode was a glassy carbon disc $\mathrm{RDE}(250 \mathrm{rpm})$; a platinum wire was the counter electrode, and silver wire immersed in electrolyte solution served as pseudo reference electrode. Both the reference electrode and the counter electrode were separated from the analyte solution by a fritted glass bridge. All solutions were deoxygenated by bubbling $\mathrm{N}_{2}$ through the solutions for $15 \mathrm{~min}$.

\section{RESULTS AND DISCUSSION}

The analytical data of the complexes are summarized in Table 1. Three series of complexes were obtained corresponding to the formulae $\left[\mathrm{Co}(\mathrm{Hdmg})_{2}(\mathrm{Gly}) \mathrm{X}\right] \cdot 3 \mathrm{H}_{2} \mathrm{O},\left[\mathrm{Co}(\mathrm{Hdmg})_{2}(\mathrm{Ser}) \mathrm{X}\right] \cdot \mathrm{nH}_{2} \mathrm{O}$ where $\mathrm{X}=\mathrm{Cl}, \mathrm{Br}$ and $\mathrm{n}=2,3$ or $\mathrm{I}$ and $\left[\mathrm{Co}(\mathrm{Hdmg})_{2}(\mathrm{HA}) \mathrm{SCN}\right]$ where $\mathrm{HA}=\mathrm{Gly}$, Ser, Cys or CysCys. The molar conductance values of all complexes in DMSO at $10^{-3}$ mol. $\mathrm{L}^{-1}$ are in the range $12-30 \Omega^{-1} \mathrm{~cm}^{2} \mathrm{~mol}^{-1}$ and suggest that the complexes are non-electrolytes.

\section{Infrared Spectra}

The main IR bands of the ligands and their metal complexes are given in Table 2. The IR spectra of amino acids show no characteristic absorption bands assignable to the function $\mathrm{NH}_{2}$ in the $3300-3500 \mathrm{~cm}^{-1}$ range, they show the $\mathrm{v}\left(\mathrm{NH}_{3}{ }^{+}\right)$frequency in the $3150-3170 \mathrm{~cm}^{-1}$ region. ${ }^{[11]}$ In glycine, cysteine and serine $v\left(\mathrm{NH}_{3}{ }^{+}\right)$is observed at 3170,3170 and 3150 $\mathrm{cm}^{-1}$, respectively. The amino acids show a band in the $1660-1620 \mathrm{~cm}^{-1}$ range. This band may be attributed to the $\mathrm{NH}_{3}{ }^{+}$deformation. ${ }^{[12]}$ Two absorption bands corresponding to the asymmetric and symmetric modes occur in the ligands near 1575 around $1410 \mathrm{~cm}^{-1}$ that can be assigned to the ionic carboxyl of the acid moiety. ${ }^{[12]}$

In the IR spectrum of $\mathrm{H}_{2} \mathrm{dmg}$, a band of medium intensity at 1447 $\mathrm{cm}^{-1}$ is assigned to the $v(C=N)$ vibration. The strong and sharp band appearing at $1444 \mathrm{~cm}^{-1}$ is due to the stretching vibration band of the $\mathrm{N}-\mathrm{O}$ group. The broad band at $750 \mathrm{~cm}^{-1}$ is attributed to $\delta(\mathrm{NOH})$ of the oxime part of the molecule.

In some cases, the characteristic IR absorption bands of the ligands are shifted to lower energy on complex formation and new bands, characteristic of the complexes, appear. The band of medium intensity occurring at around $3170 \mathrm{~cm}^{-1}$ corresponding to the $\mathrm{v}\left(\mathrm{NH}_{3}{ }^{+}\right)$frequency in the free amino acids series is shifted to $3100 \mathrm{~cm}^{-1}$ in the complexes. This is probably attributable to $v\left(\mathrm{NH}_{2}{ }^{+}\right)$. This band disappears in the serine com- 


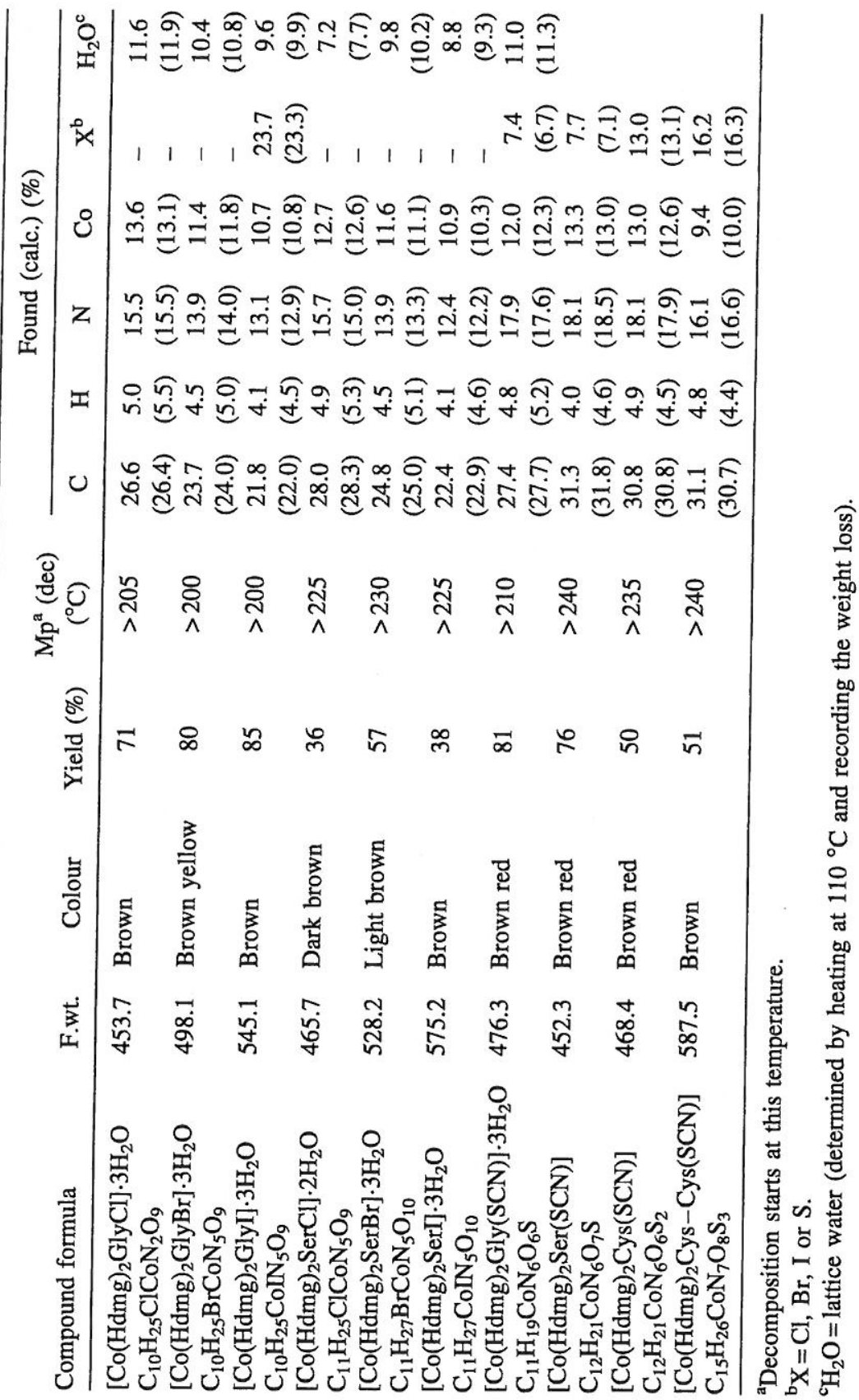




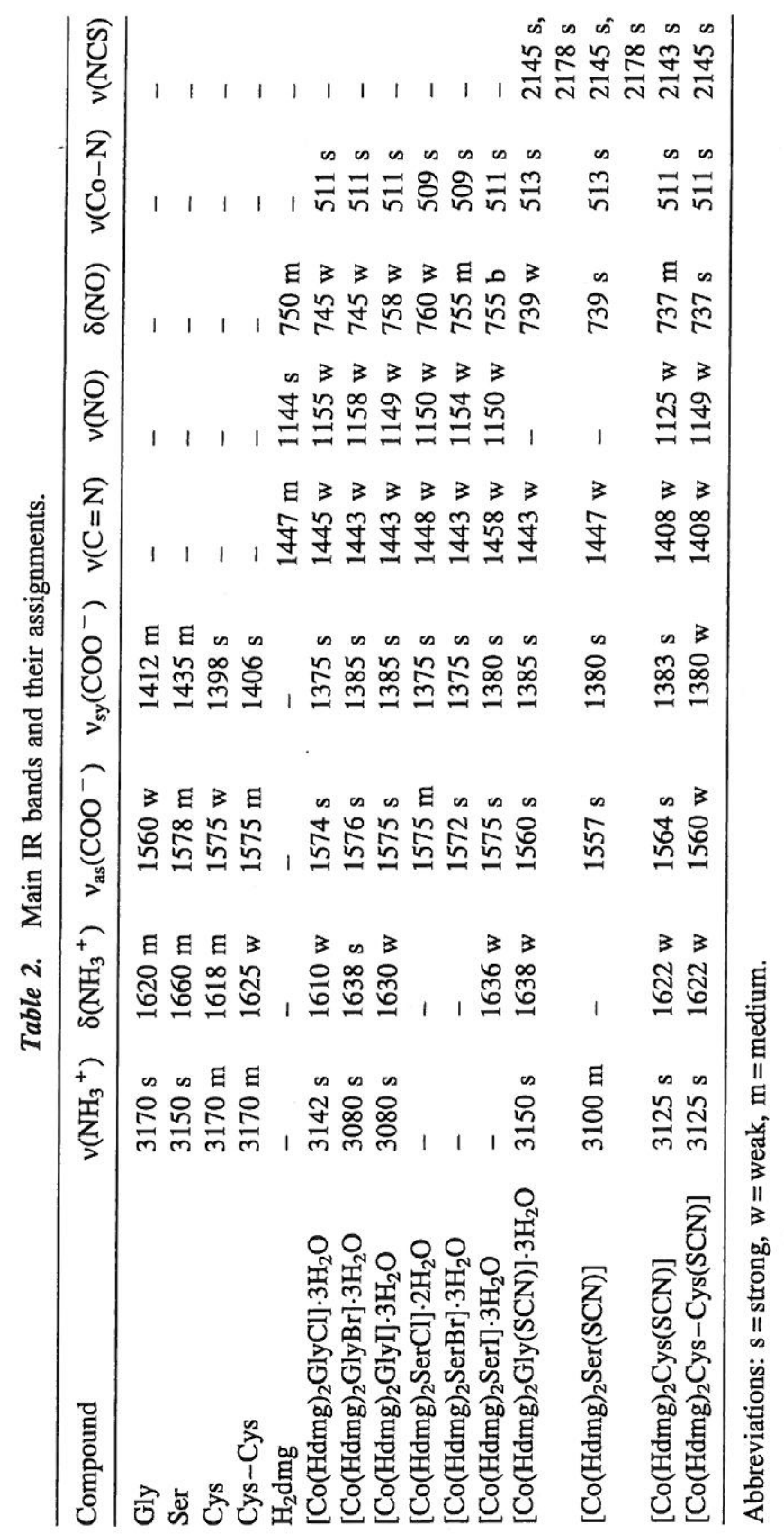


plexes. In this case, the bands may be masked by the $-\mathrm{CH}$ group absorption. All amino acids show characteristic bands in the $1660-1610 \mathrm{~cm}^{-1}$ range ${ }^{[12]}$ and these vibrations are attributed to the $\mathrm{NH}_{3}{ }^{+}$deformation. In coordination compounds, the deformation bands $\delta\left(\mathrm{NH}_{2}{ }^{+}\right)$occur in the $1610-1338 \mathrm{~cm}^{-1}$ region. This absorption is not observed in all the serine complexes because it is probably associated with an asymmetric ionic stretching vibration band of the carboxyl, $v_{\text {as }}\left(\mathrm{COO}^{-}\right)$.

The two absorption bands occurring near $1575 \mathrm{~cm}^{-1}$ and $1410 \mathrm{~cm}^{-1}$ in amino acids ${ }^{[12]}$ corresponding to the asymmetric and symmetric stretching vibration bands of the ionic carboxyl in the complexes, are shifted to lower frequencies, $1570 \mathrm{~cm}^{-1}$, as broad bands and at $1380 \mathrm{~cm}^{-1}$, as sharp bands, respectively. The IR spectra of the complexes suggest that the amino acids are coordinated through the nitrogen atom of the amino group.

The $v(C=N)$ frequency at $1447 \mathrm{~cm}^{-1}$ in free $\mathrm{H}_{2} \mathrm{dmg}$ is observed at around $1445 \mathrm{~cm}^{-1}$ in the spectra of the complexes. This suggests that the ligand is coordinated to the metal ion through the nitrogen of the oxime. ${ }^{[13]}$ The appearance of a simple band at $1447 \mathrm{~cm}^{-1}$ in $\mathrm{H}_{2} \mathrm{dmg}$ shows that the two oxime groups are identical while the appearance of a band for the complexes at around $1150 \mathrm{~cm}^{-1}$, is assignable to $\mathrm{v}(\mathrm{NO})$. The sharp band occurring in the $737-760 \mathrm{~cm}^{-1}$ region in all the complexes is assigned to $\delta(\mathrm{NOH})$. All the thiocyanato complexes exhibit a very strong and sharp band at around $2145 \mathrm{~cm}^{-1}$ assignable to the $v(\mathrm{SCN})$ vibration. ${ }^{[13]}$

The spectra of the complexes exhibit a new strong and sharp band at around $511 \mathrm{~cm}^{-1}$ which is not found in the spectra of the free ligands. In agreement with $\mathbb{R}$ spectral studies on cobaloximes ${ }^{[14,15]}$ this band is assigned to $v(\mathrm{Co}-\mathrm{N})$.

All the complexes with glycine and serine show a broad band of strong intensity at $3540 \mathrm{~cm}^{-1}$ and in a few cases at around $3450 \mathrm{~cm}^{-1}$, as excepted for $\left[\mathrm{Co}(\mathrm{Hdmg})_{2}(\mathrm{Ser}) \mathrm{SCN}\right]$. It can be attributed to the $v(\mathrm{OH})$ of water crystallisation. The IR spectra of $\left[\mathrm{Co}(\mathrm{Hdmg})_{2}(\mathrm{Cys}) \mathrm{SCN}\right]$ and $\left[\mathrm{Co}(\mathrm{Hdmg})_{2}(\mathrm{Cys}-\mathrm{Cys}) \mathrm{SCN}\right]$ do not show the presence of water of crystallization molecules.

\section{${ }^{1} \mathbf{H}$ NMR Spectra}

The chemical shift of the methyl group of dimethylglyoxime $(0.95$ ppm) shifts considerably downfield in the complexes (to around $2.30 \mathrm{ppm}$ ) indicating that this ligand is coordinated through the nitrogen atoms. The dimethylglyoximato methyl group resonances are almost invariant across the series. ${ }^{[16]}$ The complexes and $\mathrm{H}_{2} \mathrm{dmg}$ are only soluble in DMSO or 
DMF, but the amino acids are not soluble in these same solvents. Thus, we have recorded the ${ }^{1} \mathrm{H}$ NMR spectra of the amino acids using $\mathrm{D}_{2} \mathrm{O}$ solutions and all others in DMSO- $d_{6}$. It is not possible to compare the chemical shifts in different solvents; however, these spectra show unambiguously, in each case, that Hdmg coordinates through the nitrogen atoms.

\section{Electronic Spectra}

In DMSO solutions (around $5.10^{-3}$ mol. $\mathrm{L}^{-1}$ for visible and $5.10^{-5}$ mol. $L^{-1}$ for UV spectra), the spectra of the complexes show two $d-d$ transition bands and two bands due to ligand to metal charge transfer, all in the near-UV range. The positions of these bands and the molar absorption coefficients $\varepsilon$ are given in Table 3 .

The spectra in DMSO solution for the cobalt(III) complexes show two peaks of weak to moderate intensity at around $14,000-15,000 \mathrm{~cm}^{-1}$ and $17,000-18,000 \mathrm{~cm}^{-1}$ assignable to ${ }^{1} \mathrm{~A}_{1 \mathrm{~g}} \rightarrow{ }^{1} \mathrm{~T}_{1} \mathrm{~g}$ and ${ }^{1} \mathrm{~A}_{1 \mathrm{~g}} \rightarrow{ }^{1} \mathrm{~T}_{2 \mathrm{~g}}$ transitions, respectively, typical of low-spin, six-coordinated cobalt(III) complexes. ${ }^{[17]}$ The variation of the position of the $d-d$ transition bands agrees with the spectrochemical series: $\mathrm{I}<\mathrm{Br}<\mathrm{Cl}$ for the halo complexes.

Unfortunately, the first $d-d$ transition in the spectra of the thiocyanato series is not observed for all the complexes and it is not possible to classify the amino acids in increasing order of ligand field. For the thiocyanato complexes, the transition energies are quite identical. So, the amino acids involved in this series lead to an identical ligand field. This could be expected as these amino acids coordinate through the same atom: $\mathrm{N}$ from amino acid group.

Two additional bands appear in the range $20,500-26,000 \mathrm{~cm}^{-1}$ and $29,500-33,000 \mathrm{~cm}^{-1}$. These bands are due to ligand to metal charge transfer $\pi(\mathrm{L}) \rightarrow \mathrm{d}(\mathrm{Co})$ transition. They are shifted to lower energies and this order follows the decreasing electronegativity of the halogens.

The analytical data and the spectroscopic studies show that these complexes are formulated as $\left[\mathrm{Co}(\mathrm{Hdmg})_{2}(\mathrm{HA}) \mathrm{X}\right]$. The $\mathrm{Co}(\mathrm{III})$ cation presents an octahedral geometry where the two Hdmg are bounded in the equatorial positions while the monodentate amino acid and the halogenide or the thiocyanate ions are located at the free axial positions. The structure is presented on Figure 1.

\section{Electrochemical Behavior of the Complexes}

The cyclic voltammograms of these complexes in DMSO consist in four redox processes labelled I, II, III and IV. A cyclic voltammogram of 


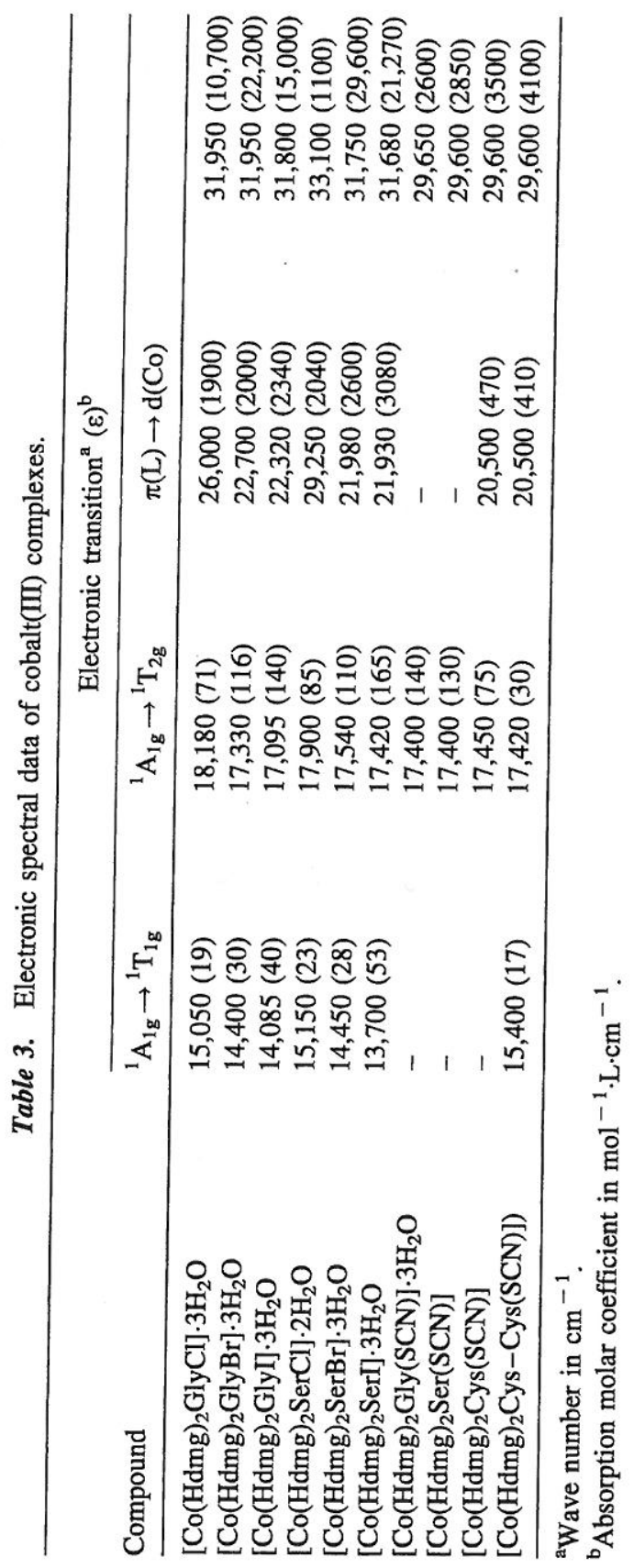




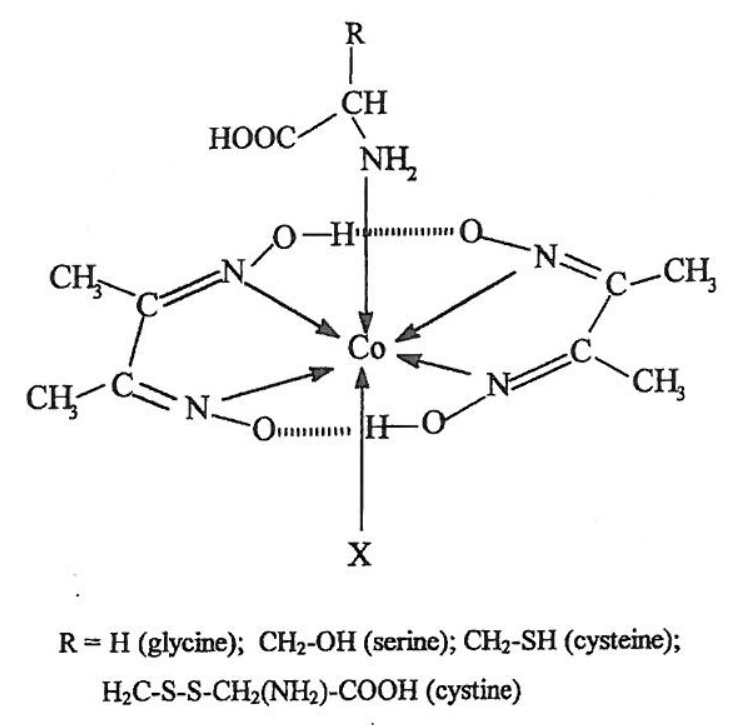

Figure 1. Suggested structures of the complexes.

$\left[\mathrm{Co}(\mathrm{Hdmg})_{2} \mathrm{SerCl}\right] \cdot 3 \mathrm{H}_{2} \mathrm{O}$ is shown in Figure 2. The cyclic voltammetric data for the oxidation and the reduction of the halo and thiocyanato complexes are presented in Table 4. The parameters, namely ipa/ipc and $\Delta \mathrm{Ep}$, used to evaluate the reversibility of the redox couples are given in the last two columns. ${ }^{[18,19]}$

Processes I and II are oxidative while processes III and IV are reductive ones. On the basis of the results reported ${ }^{[8,20]}$ on the cobaloxime complexes, the assignment of the various redox sites of the Co(III) containing complexes studied show that the redox systems III and IV are metal-based and correspond to the successive reduction processes, $\mathrm{Co}(\mathrm{III}) / \mathrm{Co}(\mathrm{II})$ and $\mathrm{Co}(\mathrm{II}) / \mathrm{Co}(\mathrm{I})$. The values of the anodic peak potentials $(\mathrm{Epa}=+0.86 \mathrm{~V})$ and cathodic peak potentials $(\mathrm{Epc}=+0.75 \mathrm{~V})$ taken from the voltammogram of $\mathrm{H}_{2} \mathrm{dmg}$, compared with those obtained for the complexes, indicate that the oxidating process I originates at the glyoximate moiety.

In order to identify the redox sites involved in the different oxidation steps, we have recorded the cyclic voltammograms of halide and thiocyanate salts under identical experimental conditions. Thus, the chloride, bromide and iodide salts undergo oxidation (Epa ranging between +0.05 and $+0.15 \mathrm{~V}$ ). The reduction is observed only for the bromide and iodide salts at -0.15 and $-0.05 \mathrm{~V}$, respectively. Whereas the voltammogram of $\mathrm{KSCN}$ shows two waves corresponding to $\mathrm{Epa}=-0.10 \mathrm{~V}$ and $\mathrm{Epc}=-0.30$ 


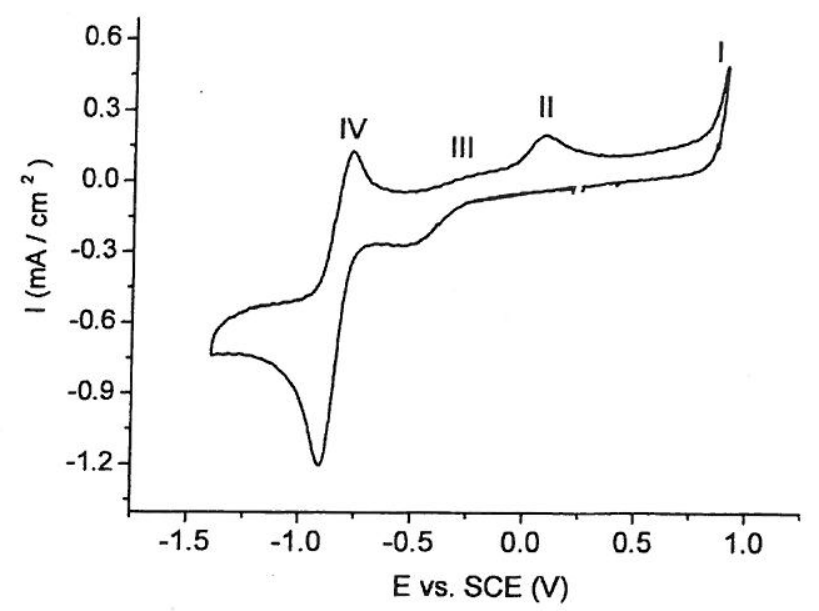

Figure 2. Cyclic voltammetric data for the reduction of $\left[\mathrm{Co}(\mathrm{Hdmg})_{2}(\mathrm{Ser}) \mathrm{C}\right] \cdot 3 \mathrm{H}_{2} \mathrm{O}$ $\left(1.10^{-3} \mathrm{M}\right)$ at a glassy carbon disc electrode containing $0.1 \mathrm{M} \mathrm{NaClO}_{4}$ at $20{ }^{\circ} \mathrm{C}$.

$\mathrm{V}$ at a scan rate of $300 \mathrm{mVs}^{-1}$. The waves corresponding to the redox system II, compared to those obtained for the salts may be attributed to the oxidation of the halide ${ }^{[20]}$ or thiocyanate ion. Similarly, it was mentioned that a wave due to the oxidation of a chloride ion is observed on the voltammogram of the complex $\left[\mathrm{Co}(\mathrm{Hdmg})_{2} \mathrm{PyCl}\right] .^{[21]}$

Complexes $\left[\mathrm{Co}(\mathrm{Hdmg})_{2}(\mathrm{HA}) \mathrm{X}\right] \cdot 3 \mathrm{H}_{2} \mathrm{O}(\mathrm{HA}=\mathrm{Gly}$, Ser and $\mathrm{X}=\mathrm{Cl}, \mathrm{Br}, \mathrm{I})$

In the case of these complexes, the oxidation processes I are irreversible as evidenced by the lack of a reduction wave during the reverse scan. The only anodic signal displayed by most of the complexes appearing at the potential Epa $\approx+0.90 \mathrm{~V}$ as process I can be attributed to the Hdmg ligand. ${ }^{[8]}$ Whereas the redox systems II show chemical reversibility $(\Delta \mathrm{Ep} \sim 70-100 \mathrm{mV}$ ) for the halo complexes. Voltammograms of salts containing $\mathrm{Cl}, \mathrm{Br}$, I and those of the complexes exhibits similar waves. This observation demonstrates that processes II corresponds to the oxidation of the halogens. For the $\mathrm{Co}$ (III)/Co(II) couple, the values of the anodic and cathodic peak potentials increase progressively in the following order of:

$$
\mathrm{Cl}<\mathrm{Br}<\mathrm{I}
$$




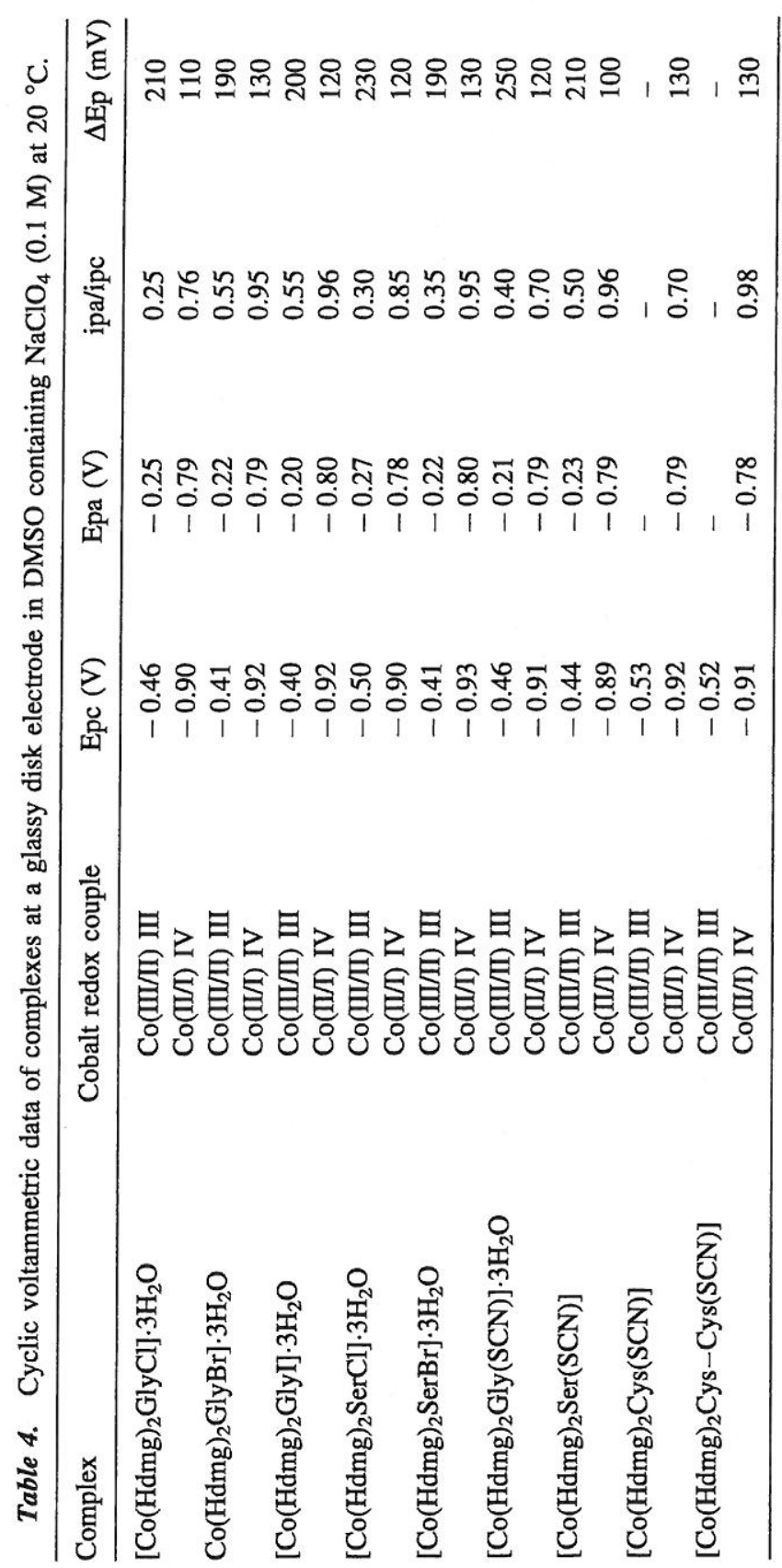


It is seen in Table 4 that for the redox system III, the ratio of the anodic peak current to the cathodic peak current ranges between 0.25 and 0.55 indicative of the irreversibility of the $\mathrm{Co}(\mathrm{III}) / \mathrm{Co}(\mathrm{II})$ couple. The separation between the anodic and cathodic peak potentials, $\Delta \mathrm{Ep}$, is large, ranging from $190 \mathrm{mV}$ to $250 \mathrm{mV}$ at the sweep rate of $400 \mathrm{mV} \mathrm{s}^{-1}$ for the $\mathrm{Co}(\mathrm{III}) / \mathrm{Co}(\mathrm{II})$ redox couple, indicative of its electrochemical irreversibility. ${ }^{[21]}$ Also, both cathodic and anodic peaks of this couple lack the characteristic sharpness of a reversible electrode reaction. The values of the anodic and cathodic potentials in Table 4 show the sensitivity of the $\mathrm{Co}(\mathrm{III}) / \mathrm{Co}$ (II) couple to the nature of the axial ligand. This phenomenon is described in the electrochemistry of cobaloximes. ${ }^{[8,15,21]}$

The anodic waves corresponding to the oxidation of $\mathrm{Co}(\mathrm{II})$ to $\mathrm{Co}(\mathrm{III})$ were poorly resolved, for the same couple, the cathodic peaks shift to potentials that are more negative with increasing sweep rate, confirming the character of an irreversible system.

The causes of the irreversibility may be attributed to extensive bond breaking during the reduction of the $\left[\mathrm{Co}(\mathrm{III})(\mathrm{Hdmg})_{2}(\mathrm{HA}) \mathrm{X}\right] \cdot 3 \mathrm{H}_{2} \mathrm{O}$ complex. Thus, the axial ligand $\left(\mathrm{X}^{-}\right)$is lost and the formation of a five-coordinate $\mathrm{Co}(\mathrm{II})$ complex is envisioned. ${ }^{[18]}$

$$
\begin{aligned}
& {\left[\mathrm{Co}(\mathrm{III})(\mathrm{Hdmg})_{2}(\mathrm{HA}) \mathrm{X}\right] \cdot 3 \mathrm{H}_{2} \mathrm{O}+\mathrm{e}} \\
& \quad \rightarrow\left[\mathrm{Co}(\mathrm{II})(\mathrm{Hdmg})_{2}(\mathrm{HA})\right]+\mathrm{X}^{-}(\mathrm{X}=\mathrm{Cl}, \mathrm{Br}, \mathrm{I})
\end{aligned}
$$

In the case of the $\mathrm{Co}(\mathrm{II}) / \mathrm{Co}(\mathrm{I})$ redox couple, the separation between the anodic and cathodic peak potentials span the $100-130 \mathrm{mV}$ range at all sweep rates and the ipa/ipc ratio $\approx 0.75-0.95$, indicating the electrochemical reversibility of the couple. The observed insensitivity of the $\mathrm{Co}(\mathrm{II}) /$ $\mathrm{Co}(\mathrm{I})$ couple to the nature of the various axial ligands also has been described in previous works on cobalt complexes. ${ }^{[8,18,21]}$ The invariance of the position of the cathodic peak corresponding to the process $\mathrm{Co}(\mathrm{II}) \rightarrow \mathrm{Co}(\mathrm{I})$ is probably due to the weak axial interactions in these cobalt(II) complexes which are considered to be five-coordinate.

\section{Complexes $\left[\mathrm{Co}(\mathrm{Hdmg})_{2}(\mathrm{HA}) \mathrm{SCN}\right](\mathrm{HA}=\mathrm{Gly}$, Ser, Cys and Cys-Cys $)$}

The thiocyanato complex exhibits the same voltammetric behavior as does the halo complex. However, for these compounds only one anodic peak corresponding to the system II is well observed but the wave potentials Epc are very poorly defined. Consequently, this redox system displays a lesser degree of reversibility than the halo complexes. 
For the complexes of cysteine and cystine the waves corresponding to the oxidation of the $\mathrm{Co}(\mathrm{III}) / \mathrm{Co}$ (II) couple are not well resolved, confirming the irreversible character of the couple. The separation between the anodic and cathodic peak potentials, $\Delta \mathrm{Ep}$, is higher $(210-250 \mathrm{mV}$ ) indicating a slow electron transfer for this couple.

When the complexes undergo reduction from $\mathrm{Co}(\mathrm{I}) \rightarrow \mathrm{Co}(\mathrm{I})$, the ratio ipa/ipc $\approx 0.96-0.98$ indicates that the couple has chemical reversibility. Further, for the $\left[\mathrm{Co}(\mathrm{Hdmg})_{2} \mathrm{CysSCN}\right]$ and $\left[\mathrm{Co}(\mathrm{Hdmg})_{2} \mathrm{GlySCN}\right] \cdot 3 \mathrm{H}_{2} \mathrm{O}$ complexes, the $\mathrm{Co}(\mathrm{II}) / \mathrm{Co}(\mathrm{I})$ couple exhibits poor reversibility (ipa/ ipc $=0.70$ ). In this case, a chemical reaction is probably coupled to the electrochemical reaction.

\section{ACKNOWLEDGMENT}

We thank the "Comité Mixte d' Evaluation et de Prospective de la Coopération Inter Universitaire Franco-Algérienne” (CMEP), for financial support of this work.

\section{REFERENCES}

1. Bresciani-Pahor, N.; Zangrando, E.; Antolini, I. Structures of two triphenylphosphine cobaloximes, $\mathrm{PPh}_{3} \mathrm{Co}(\mathrm{DH})_{2} \mathrm{X}$ with $\mathrm{X}=$ dichlorocyanomethyl and isocyanate. Acta Crystallogr. 1990, C46 (10), 17931795.

2. Megnamisi-Belombe, M.; Nane Nlend, G.; Nuber, B. Crystal and molecular structure of the asymetric cobaloxime, trans-bis(2,3-butanedionedioximato(1-)-N, $\left.\mathrm{N}^{\prime}\right)$ iodopyridine cobalt(III): [Co(Hdmg $\left.)_{2} \mathrm{I}(\mathrm{py})\right]$. Bull. Chem. Soc. Jpn. 1992, 65 (2), 612-614.

3. Solans, X.; Font-Bardia, M.; Lopez, C.; Alvarez, S. Anhydrous trans(aniline) chlorobis(dimethylglyoximato)cobalt(III). Acta Crystallogr. 1996, C52, 63-66.

4. Bresciani-Pahor, N.; Farcolin, M.; Marzilli, L.; Randaccio, L.; Summers, M.F.; Toscano, P.J. Organocobalt $\mathrm{B}_{12}$ models: Axial ligand effects on the structural and coordination chemistry of cobaloximes. Coord. Chem. Rev. 1985, 63, 1-125.

5. Sekine, A.; Ohashi, Y.; Hori, K. Structure of (2-cyanomethyl)(3-cyanopyridine)bis[dimethyglyoximato(1-)]cobalt(III) monohydrate (I) and (4-aminopyridine)(2-cyanoethyl)-bis[dimethylglyoximato(1-)]cobalt(III) (II). Acta Cryst. 1991, 47 (3), 525-528.

6. Geremia, S.; Randaccio, I.; Zangrando, E.; Antolini, I. Evidence of steric 
influence on the $\mathrm{Co}-\mathrm{C}$ bond lenghts in vitamin $\mathrm{B}_{12}$ model compounds. Crystal structures of adamantyl cobaloximes with the neutral ligands $\mathrm{H}_{2} \mathrm{O}$ and $\mathrm{PPh}_{3}$ Et. J. Organomet. Chem. 1992, 425 (1), 131-139.

7. Hoshino, M.; Konishi, S.; Teral, Y.; Imamura, M. Optical and ESR studies of the one-electron reduction of alkylcobaloximes in rigid matrices. Inorg. Chem. 1982, 21, 89-93.

8. Ngameni, E.; Nassi, A.; Ngoune, J.; Megnamisi-Belombe, M.; Roux, R. Electrochemical and spectroscopic behavior of trans-bis(ethandialdioximato(1-(N,N')-diodocobaltate(III). Electrochim. Acta 1995, 40 (15), 2533-2539.

9. Toscano, P.J.; Brand, H.; Geremia, S.; Randaccio, I.; Zangrando, E. Evidence for steric trans Influences and effects in (perfluoroisopropyl)cobaloximes. Molecular structure of trans-bis(dimethyglyoximato)(triphenylphosphine)-(perfluoroisopropyl)cobalt(III). Polyhedron 1991,10 (3), 713-720.

10. Adkhis, A.; Benali-Baïtich, O.; Khan, M.A.; Bouet, G. Synthesis, characterization and thermal behavior of mixed-ligand complexes of cobalt(III) with dimethylglyoxime and some amino acids. Synth. React. Inorg. Met.-Org. Chem. 2001, 30 (10), 1849-1858.

11. Bellamy, L.J. The Infrared Spectra of Complex Molecules, 3rd Ed.; J. Wiley: New York, 1975; 226.

12. Saxena, V.K.; Gupta, M.; Srivastava, M.N. Synthesis and characterization of complexes of copper(II), nickel(II), cobalt(II) and zinc(II) with histidine and glycine or alanine. Synt. React. Inorg. Met.-Org. Chem. 1996, 26 (10), 1661-1676.

13. Alexander, V.A. Detailed infrared and far-infrared spectral investigation of the alkyl- and (non-alkyl) cobalt(III) complexes of 3,8-dimethyl5.6-benzo-4.7-diazadeca-3,7-diene-2,9-dione dioxime and study of ground state trans-effects in tetragonally distorded octahedral cobalt(III) complexes by far-infrared and electronic absoption spectroscopy. Inorg. Chim. Acta 1993, 204, 109-124.

14. Mohapatra, M.; Chakravortty, V.; Dash, K.C. Cobalt(II) and cobalt(III) complexes with hexadentate dioxime Schiff base ligands. Polyhedron 1989, 8 (12), 1509-1515.

15. Yamazaki, M.; Hohokabe, Y. Studies on cobaloxime compounds. Synthesis of various cobaloximes and investigation on their infrared and far-infrared spectra. Bull. Chem. Soc. Jpn. 1971, 44, 63-69.

16. Ware, D.C.; Mackie, D.S.; Brothers, P.J.; Denny, W.A. Synthesis and characterization of mono- and bis-aziridine bis-dimethylglyoximatocobalt(III) complexes. Polyhedron 1993, 12 (11), 1371-1376.

17. Lever, A.B.P. Inorganic Electronic Spectroscopy, 2nd Ed.; Elsevier: Amsterdam, 1984; 473. 
18. Alexander, V.; Ramanujam, V.V. Vitamine $\mathrm{B}_{12}$ and coenzyme $\mathrm{B}_{12}$ models. An electrochemical investigation on alkyl- and (non-alkyl)cobalt(III) complexes of 3,8 dimethyl-5,6-benzo-4,7-diazadeca-6,7-diène2,9-dione dioxime by cyclic voltammetry and polarography. Inorg. Chim. Acta 1989, 156, 125-137.

19. Alexander, V. Synthesis, characterization and spectrochemistry, electrochemistry and Spectrochemistry of bromo (Lewis base) cobalt(III) complexes of 3,8-dimethyl-5.6-benzo-4.7-diazadeca-3,7-diene2,9-dione dioxime. Inorg. Chim. Acta 1989, 163, 25-40.

20. Ngameni, E.; Nassi, A.; Ngoune, J.; Megnamisi-Belombe, M.; Roux, R. Electrochemical studies and electronic spectroscopic of some cobaloximatic complexes based on 2,3-butanedione dioxime or dimethyglyoxime identical or mixed axial ligands. Electrochim. Acta 1996, 41 (16), 2571-2577.

21. Gerli, A.; Marzilli, L.G. Costa-type $B_{12}$ models: Synthesis, structural characterization, and electrochemistry of chloro derivatives. Inorg. Chem. 1992, 31, 1152-1160.

Received February 7, 2002

Accepted August 31, 2002
Referee I: P. J. Toscano

Referee II: A. I. Odom 